Azeem, A.H.A., Mallawarachi, H. and Geekiyanage, D., 2019. Building organisational capacities for effective e-waste management: A conceptual framework. In: Sandanayake, Y.G., Gunatilake, S. and Waidyasekara, A. (eds). Proceedings of the $8^{\text {th }}$ World Construction Symposium, Colombo, Sri Lanka, 8-10 November 2019, pp. 158-167. DOI: doi.org/10.31705/WCS.2019.16. Available at: https://2019.ciobwcs.com/papers

\title{
BUILDING ORGANISATIONAL CAPACITIES FOR EFFECTIVE E-WASTE MANAGEMENT: A CONCEPTUAL FRAMEWORK
}

\author{
A.H.A. Azeem ${ }^{1}$, H. Mallawarachi ${ }^{2}$ and D. Geekiyanage ${ }^{3}$
}

\begin{abstract}
Globally, e-waste generation rises in parallel to the increased consumption of e-products. Management of this complex waste stream becomes a severe challenge, especially for developing countries. Sri Lanka also no exception to this problem due to the limited capacities of e-waste handling organisations in the country. Therefore, this study aims to develop a conceptual framework for effective e-waste management by integrating organisational capacities to improve the involvement of organisations for effective e-waste management. Initially, a comprehensive literature review was carried out on the state-of-art of the e-waste management, capacity buildings, and application of organisational capacities for e-waste management alike. The review of the literature revealed that there are eight dimensions to measure organisational capacities. They are mission and strategy, organisational structure, processes, human resources, financial resources, information resources, and infrastructure. The data collected from the literature review was manually analysed and finally, the conceptual framework was developed on organisational capacity buildings for effective e-waste management. The developed conceptual framework can be used as a guideline to implement organisational capacities for e-waste management. This framework will be a blueprint for individuals and organisations to incorporate dimensions of organisational capacity buildings to ewaste management by identifying the existing capacity gaps consequently, enhancing the organisational capacity for better managing the e-waste, especially in developing countries.
\end{abstract}

Keywords: Capacity Buildings; Capacity Gaps; Developing Countries; E-Waste Management; Organisational Capacity.

\section{INTRODUCTION}

Rapid development in the global economy, growing population, market penetration and exponential growth in technological innovation and product obsolescence fuelling the generation of the e-waste (Li et al., 2015). In worldwide, generation of e-waste has risen gradually together with an annual growth rate of $4-5 \%$. The global e-waste generation of 41.8 million metric tonnes (MT) in 2014 represents the $1-3 \%$ of municipal waste, and it is expected to reach 50 million MT by 2018 (Wath et al., 2010). Furthermore, in developing countries, on average total e-waste generation represents $1 \%$ of total solid waste generation and it is forecasted to be increased by $2 \%$ annually (United Nations Environment Programme [UNEP], 2010). Indeed, developing countries' e-waste flow

\footnotetext{
${ }^{1}$ Department of Building Economics, University of Moratuwa, Sri Lanka, aseem1995aha@gmail.com.

2 Department of Building Economics, University of Moratuwa, Sri Lanka, hmallawarachchi@gmail.com.

${ }^{3}$ Department of Building Economics, University of Moratuwa, Sri Lanka, d.geekiyanage22@gmail.com.
} 
will likely to overtake the developed countries by 2030 (Li et al., 2015; Sthiannopkao and Wong, 2013;).

Similarly, Ratnayake et al. (2016) stated that the penetration of electrical and electronic equipment (e-products) market has considerably increased in Sri Lanka in recent decades. In line with that, management of the e-waste has become a critical concern in Sri Lanka to ensure that this e-waste does not dumb into landfills or watersides (Accounting and Financial Management Association [AFMA], 2015). Besides, most industrialised countries use advanced technologies, state of the art of facilities, and a high degree of mechanization for the management of e-waste (Li et al., 2015). Consequently, leading organisations have contributed to an upstream reduction of e-waste through product redesign and recyclable components (Nnorom and Osibanjo, 2008). However, Adediran and Abdulkarim (2012) argued that there are considerable capacities gaps in developing countries in the management of the e-waste in terms of policies, institutional framework, infrastructure, and amongst others. Sri Lanka is also no exception to these capacity gaps in the proper management of e-waste (Suraweera, 2016).

Therefore, addressing the limited capacities in organisations is a timely need to boost the organisations' in line with proper management of e-waste. This study is undertaken to integrate the organisational capacities into e-waste management and thereby to develop a conceptual framework to improve the organisational capacities for effective e-waste management, especially in developing countries.

\section{RESEARCH METHODS}

A comprehensive literature review was carried out to gain an in-depth understanding of the e-waste management, importance of managing e-waste, importance of enhancing organisational capacities building, which was discussed on both international and local context. This study was accomplished by referring the books, journal articles, conference proceedings, governments reports, and websites. A summary profile of literature sources referred to is presented in Table 1.

Table 1: The profile of literature sources referred for the study

\begin{tabular}{|c|c|c|c|c|c|c|}
\hline \multirow[t]{2}{*}{ Sources } & \multicolumn{3}{|c|}{ Focused Area } & \multicolumn{2}{|c|}{ Quantity } & \multirow{2}{*}{$\begin{array}{c}\text { Period of } \\
\text { Publications }\end{array}$} \\
\hline & E-waste & $\begin{array}{l}\text { Capacity } \\
\text { building }\end{array}$ & Both & No. & $\%$ & \\
\hline Journal Articles & 18 & 22 & 07 & 47 & 70 & $2004-2017$ \\
\hline Government Reports & 03 & 07 & - & 10 & 15 & $1998-2017$ \\
\hline Conference Papers & 05 & 01 & - & 06 & 09 & $2003-2016$ \\
\hline Books & 01 & 02 & - & 03 & 05 & $1995-2015$ \\
\hline Website & 01 & - & - & 01 & 01 & 2017 \\
\hline Total & 28 & 32 & 07 & 67 & 100 & \\
\hline
\end{tabular}

Amongst, the majority (70\%) of the literature sources are indexed journal articles which are published during the recent 20 years. Next, 10 number of government reports $(15 \%)$ that are published in the global context and by the government of Sri Lanka were referred and most of the statistics about e-waste generation and control were extracted. Besides, six conference publications, three books on e-waste management and capacity buildings, and one website were reviewed for the collection of required data and to obtain 
knowledge for the development of the conceptual framework for building organisational capacities for effective e-waste management, particularly for developing countries.

\section{LITERATURE REVIEW}

\subsection{CurRent Status of E-Waste Management}

Even though there is no common definition, proper definition and identification of categories of e-waste are critical for the sound management of e-waste. Therefore, the definition given in the directive of the 2002/96/EC on the waste of electrical and electronic equipment (WEEE) identified as broad and widely used definition around the globe. Accordingly, in this research, the e-waste is defined as "Electrical and electronic equipment, all components, subassemblies and consumables which are part of the discarding product" (EU, 1975 as cited in Ejiogu, 2013). Consequently, Garlapati (2016) stated that this e-waste stream is highly produced in developed countries, China is identified as the substantial contributor of e-waste that is of 12.2 million MT followed by the United States which about 11 million MT. Further to the author, similarly as of developed countries, the flow of e-waste is gradually increasing in developing countries. In India, e-waste is growing at a compounded annual growth rate of about $25 \%$ and is estimated to generate 15 lakh MT of e-waste by 2015 (Garlapati, 2016).

Currently, in Sri Lanka, approximately 10,000 MT of non-white goods such as mobile phones and PCs, etc., are estimated to be generated annually (Central Environmental Authority [CEA], 2016). Further to report, amongst, only $8 \%$ of e-waste is collected and exported to other countries. About $92 \%$ of goods are stored or disposed of in a haphazard manner (CEA, 2016). Further, usage of personal computers has increased from 1993 to 2000 and it is estimated to be 17.5 times per capita basis (Ministry of Environment and Natural Resources [MENR], 2008). Besides, the government of Sri Lanka has established 1005 telecentres throughout the island under the e-Sri Lanka initiative programme (Information and Communication Technology Agency [ICTA], 2017). It let to increasing of imports of information and communication technology (ICT) goods in the country while increasing the imports of ICT goods from 2.9 - $4.2 \%$ within a period five years (World Bank, 2017). Therefore, CEA (2016) mentioned that with the growing penetration of electrical and electronic equipment, annual e-waste generation in the country is estimated at 20,000 MT and it is expected to reach about 43,000 MT per year in 2030. With this growing e-waste generation, the toxic substances in e-waste streams could have a serious risk to human health, leaches soil and contaminate the environment as there is no proper mechanism for its management (Begum, 2013).

Tran and Salhofer (2016) identified the stages involve in the e-waste management process from generation to final disposal which depicts in Figure 1. These subsequently connected steps of e-waste recycling are required to liberate the target materials and to further refine them separately (Baldé et al., 2015). Dutta and Goel (2017) insisted that effective and proper solutions are required for the proper management of e-waste. 


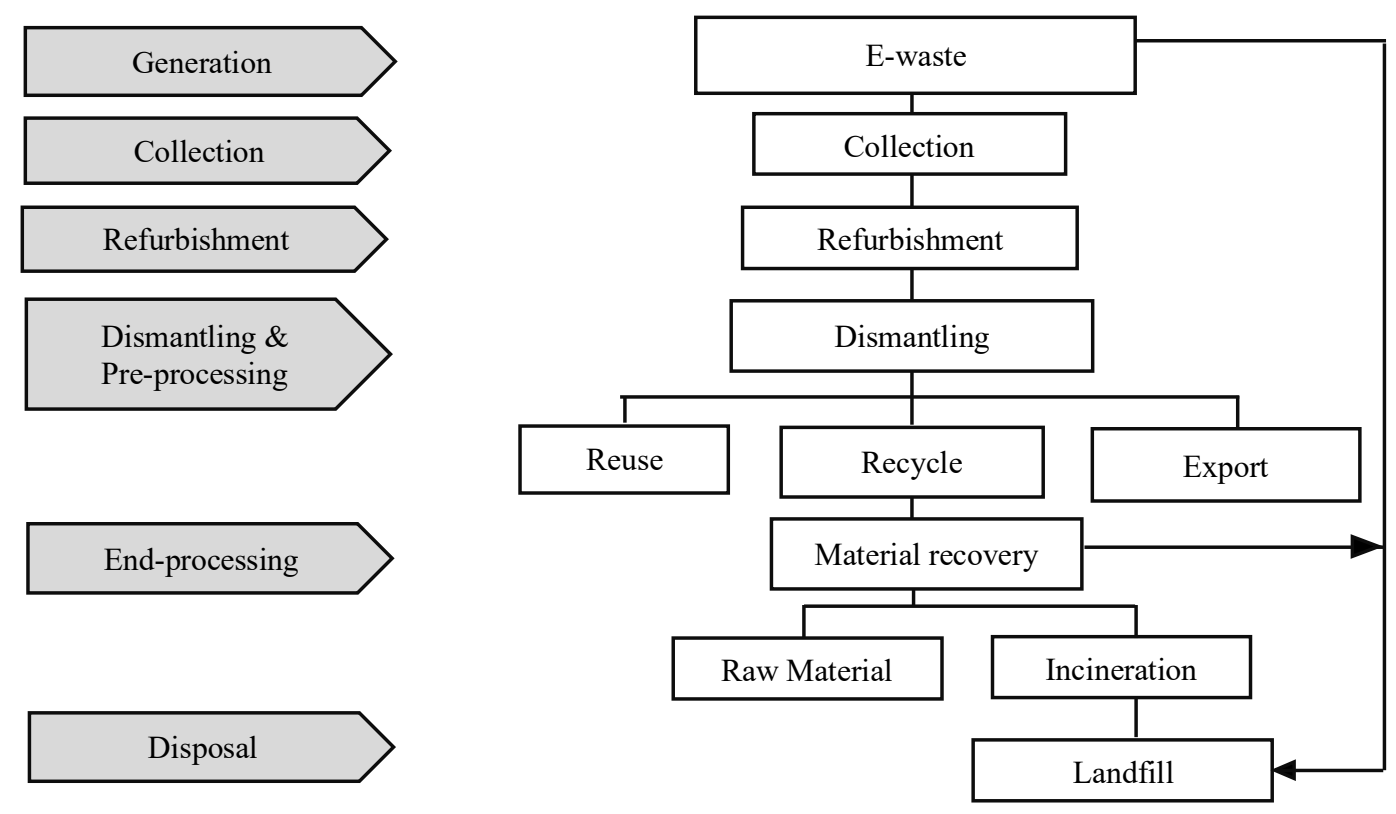

Figure 1: E-waste management process (Source: Adapted from Jang and Kim, 2010; Tran and Salhofer, 2016)

\subsection{CAPACITY NeEDS FOR E-WASTE MANAGEMENT}

The rapid product obsolescence in the electronics industry has caused significant growth in global e-waste generation. Consequently, safer management of e-waste is becoming a major problem for many countries around the globe. Heeks et al. (2015) stated that developing countries, in particular, face challenges in managing the growing e-waste problem. For example, in Africa there are highly ineffective and inefficient infrastructure facilities for e-waste management, more precisely there is no well-established system for separation, sorting, storage, collection, transportation and disposal of e-waste (Bhutta et al., 2011). More importantly, there is an absence or ineffective enforcement of legislation related to e-waste management and disposal (Nnorom and Osibanjo, 2008). Therefore, leading multi-national companies fully adhered to the principle of developed countries where strict regulation are enforced, are being free from taking the fullest responsibility of product throughout its entire lifecycle in developing countries (Kibert, 2004).

It causes the obsolete or scrap of e-products not being collected for appropriate management in most developing countries (Nnorom and Osibanjo, 2008). Kalpana and Prabhavathi (2016) identified that absences of e-waste collection lead to store about $75 \%$ of the e-waste in unattended houses, offices, etc. Finally, the management of this e-waste is taking place through traditional methods of municipal solid waste management (MSW) namely landfilling or incineration (Nnorom and Osibanjo, 2008). Besides, Jadhav (2013) stated that probably the e-waste is given to the informal collectors who pay some amount to the consumer. Consequently, informal and inappropriate handling of e-waste causing serious environmental and human health issues. Accordingly, Adediran and Abdulkarim (2012) stated that no public awareness has been done by public and private sectors on the adverse effects of improper handling of e-waste. Moreover, consumers are not aware of the e-waste collection centres, rules and proper e-waste disposal practices (Sivathanu, 2016).

It is one of the examples of poor corporate social responsibility of electronic industries (Adediran and Abdulkarim, 2012). Furthermore, in most developed countries, consumer 
finance to recycle their e-waste ( $\mathrm{Li}$ et al., 2015). Further to authors, it's regrettable; endusers in developing countries tend to sell their e-waste to the collectors who offer them better collection price. Therefore, organisations struggled in collecting funds, to invest in profitable improvements in e-waste recycling is emerged (Nnorom and Osibanjo, 2008).

Several initiatives have been undertaken in Sri Lanka to effectively manage the end of life of the electronic equipment (Suraweera, 2016). Subsequently, CEA has introduced the guidelines on the proper management of the e-waste (CEA, 2016). In addition to that, CEA has introduced the "National Corporate E-waste Management Program" with the participation of 19 private sector companies (CEA, 2016). Rodrigo (2013) mentioned that these companies accept to collect the respective end of life e-products through their designated service centres. However, evidence proved that these collaborative projects malfunction due to various reasons such as unavailability of any special strategies in the organisation for collection and it is not being implemented up to expected standards (Thavalingam and Karunasena, 2016). Ratnayake et al. (2016) further stated that most of the people are willing to support for the implementation of proper e-waste management in the urban area if they get enough support facilities for convenient and accessible ewaste collection centres. However, due to the absence of enough support facilities, these hazardous wastes are currently disposed of in roadsides, dump yards, stores and home gardens. Similarly, Ratnayake et al. (2016) specified that for example, 8 MT of e-waste accumulates for every two days within the urban area of the Gampaha district. Moreover, it is about $80 \%$ of the household sector of the Jaffna district keeping their e-waste at home, similarly, all the public offices following the same act of keeping the e-waste in stores until they are auctioned (Kayathiri et al., 2014). Even though organisations used several strategies to create awareness among the public, it resulted in giving only shortterm effects (Thavalingam and Karunasena, 2016). Authors further added that informal collectors engaged in the collection of e-waste using an unsophisticated technique to obtain precious metals from the e-waste have caused serious environmental and health issues. Furthermore, Mallawarachchi and Karunasena (2012) stressed that most organisations are at the basic stage of the e-waste management process and there is no special concern given to manage the e-waste. Further to the author, there is a lack of coordination between these government and private organisations in implementing the ewaste management procedures. Similarly, cooperation between formal and informal ewaste recycling companies is also in very minimal level in the country (CEA, 2016). Moreover, most organisations confronted with financial constraint in implementing the e-waste management process in organisations (Mallawarachchi and Karunasena, 2012). Due to the visible capacity gaps in the organisations, CEA (2016) has concluded that there was limited capacity in managing e-waste within the context of Sri Lanka.

Considering the challenges of managing the e-waste in developing countries, the electronic industries seemed to be not matured enough for managing the e-waste in these countries. Even though electronic industries cannot properly manage the e-waste, manufacturers of e-product are required to take the fullest responsibility for their products throughout its lifecycle (Ladou and Lovegrove, 2008). Therefore, Karunasena and Amaratunga (2015) stated that capacity building is necessary due to a lack of financial, institutional, technological and infrastructure capacities and access to knowledge to deal with risks and benefits. Therefore, it is necessary that existing capacities gaps in organisations need to be addressed to manage the rapid growth of the e-waste stream in the country. Accordingly, the concept of capacity building chosen to build the capacity 
of the organisations as a means to promote environmentally sound management of ewaste in Sri Lanka.

\subsection{IMPORTANCE OF ORGANISATIONAL CAPACITY BUILDING FOR E-WASTE MANAGEMENT}

The organisational capacity building focuses on the overall organisational performance and functioning capabilities as well as the ability of an organisation to adapt to change (Blokland et al., 2010). The organisational approach considers an entity, organisation or even a set of organisations as key to development (Lusthaus et al., 1995). Enemark and Williamson (2004) mentioned that an entity may be a formal organisation such as government or one of its departments or agencies, a private sector operation or an informal organisation such as community-based or volunteer organisation. The report of (UNDP, 1998) specified that traditional capacity development of the entity level focuses their development resources almost entirely on human resources, processes and organisational structures. The study further mentioned that, instead of focusing only in these areas, it should examine all dimensions of capacity at entity level including its interactions within the system, usually with other entities, stakeholders or clients, if the development initiatives to be successful.

It is due to that the organisational capacity building is complicated by multiplicity of environmental factors and also the organisations' function within the broad level, sometimes overlapping and often have complex contexts with laws, regulations, ordinances, policies and other government, community and donor priorities (US Agency for International Development [USAID], 2011). The context provides incentives to the organisations, which in turn stimulates them to act in certain manners, some incentives foster productivity, growth and capacity development, while others foster passivity, decline or even closer (Organisation for Economic Co-Operation and Development [OECD], 2006). Consequently, Table 2 provides detailed descriptions of dimensions of capacity at the organisational level which are used to measure the capacity of the organisation.

Table 2: Descriptions of dimensions at the organisational level

\begin{tabular}{l}
\hline Dimensions at \\
$\begin{array}{c}\text { Organisational } \\
\text { Level }\end{array}$ \\
\hline
\end{tabular}

Mission and

Strategy organisation and help keep it on course in service of its mission. This includes role, mandate, the definition of services, clients or customer served, interactions within the broader system and stakeholder, the measures of performance and success, and the presence of core strategic management capacities

Organisational It includes organizational and management values, management style, and Structure understanding organizational and managerial structures, designs, core competencies and standards within an entity or organization

Processes It means supporting such functions as planning, client management, relationships with other entities, research or policy development, monitoring and evaluation, performance or quality management, financial and human resources management, etc. processes are central to improve capacities 


\begin{tabular}{|c|c|}
\hline $\begin{array}{c}\text { Dimensions at } \\
\text { Organisational } \\
\text { Level }\end{array}$ & Descriptions \\
\hline $\begin{array}{l}\text { Human } \\
\text { Resources }\end{array}$ & $\begin{array}{l}\text { This is the most valuable resources in an organisation. Human resources } \\
\text { management practices become vital in an organization's ability to achieve } \\
\text { its goals. The study further added that the individual's goals apart from the } \\
\text { organizational goals should be well defined and understandable and it } \\
\text { would help to measure the performance of every one of an organization }\end{array}$ \\
\hline $\begin{array}{l}\text { Financial } \\
\text { Resources }\end{array}$ & $\begin{array}{l}\text { The financial resources include both operating and capital finance which } \\
\text { are the part of the assets of the organization. Financial resources need to be } \\
\text { managed to maximize the corporate value and to reduce the firm's } \\
\text { financial risk }\end{array}$ \\
\hline $\begin{array}{l}\text { Information } \\
\text { Resources }\end{array}$ & $\begin{array}{l}\text { Identifying how the available information resources (all media, electronic } \\
\text { and paper) are managed to support the mission and strategies of the entity }\end{array}$ \\
\hline Infrastructure & $\begin{array}{l}\text { It includes the assessment of existing infrastructures in terms of physical } \\
\text { assets such as property, building, computer system and telecommunication } \\
\text { infrastructure, productive work environments }\end{array}$ \\
\hline
\end{tabular}

Source: Adapted from Enemark and Williamson (2004); Imbaruddin (2005); Lusthaus et al. (1995); Siano et al. (2010); UNDP (1998)

\subsection{The CONCEPTUAL FraMEWORK FOR BUILDING ORGANiSATIONAL CAPACITIES FOR E-WASTE MANAGEMENT}

The framework exhibits the organisational level capacity dimensions for e-waste management, which facilitates a basis to investigate the existing organisational capacities and gaps of the capacities for e-waste management. The developed conceptual framework is illustrated in Figure 2.

In the developed framework, the organisational capacity can be assessed under eight capacity dimensions specified by the UNDP, namely, mission and strategy, organisational structure, processes, human resources, financial resources, information resources, infrastructure resources. In a different viewpoint, the identified capacity gaps in organisational buildings can be eliminated and/or minimised by the integration of identified strategies for improvement. Initially, the organisational mission and strategies need to revise incorporating potential e-waste management policy, activities and an appropriate financial plan needs to be formed. Next, a responsible party/authority towards the e-waste management need to be appointed and placed within the organisational structure. It is essential to implement the required processes to improve the current management of e-waste and minimise the existing capacity gaps. It means supporting such functions as planning, client management, relationships with other entities, research or policy development, monitoring and evaluation, performance or quality management, financial and human resources management, etc. It is vital to allocate necessary and sufficient amount of human and financial resources to support the implementation of the set process towards effective e-waste management. As the continual improvement of the process, it is required to observe and evaluate the performance of allocated resources and infrastructure to know how effectively they have achieved the set outcomes. Finally, the appropriate changes and possible improvements can be done to further improve improved e-waste management. 


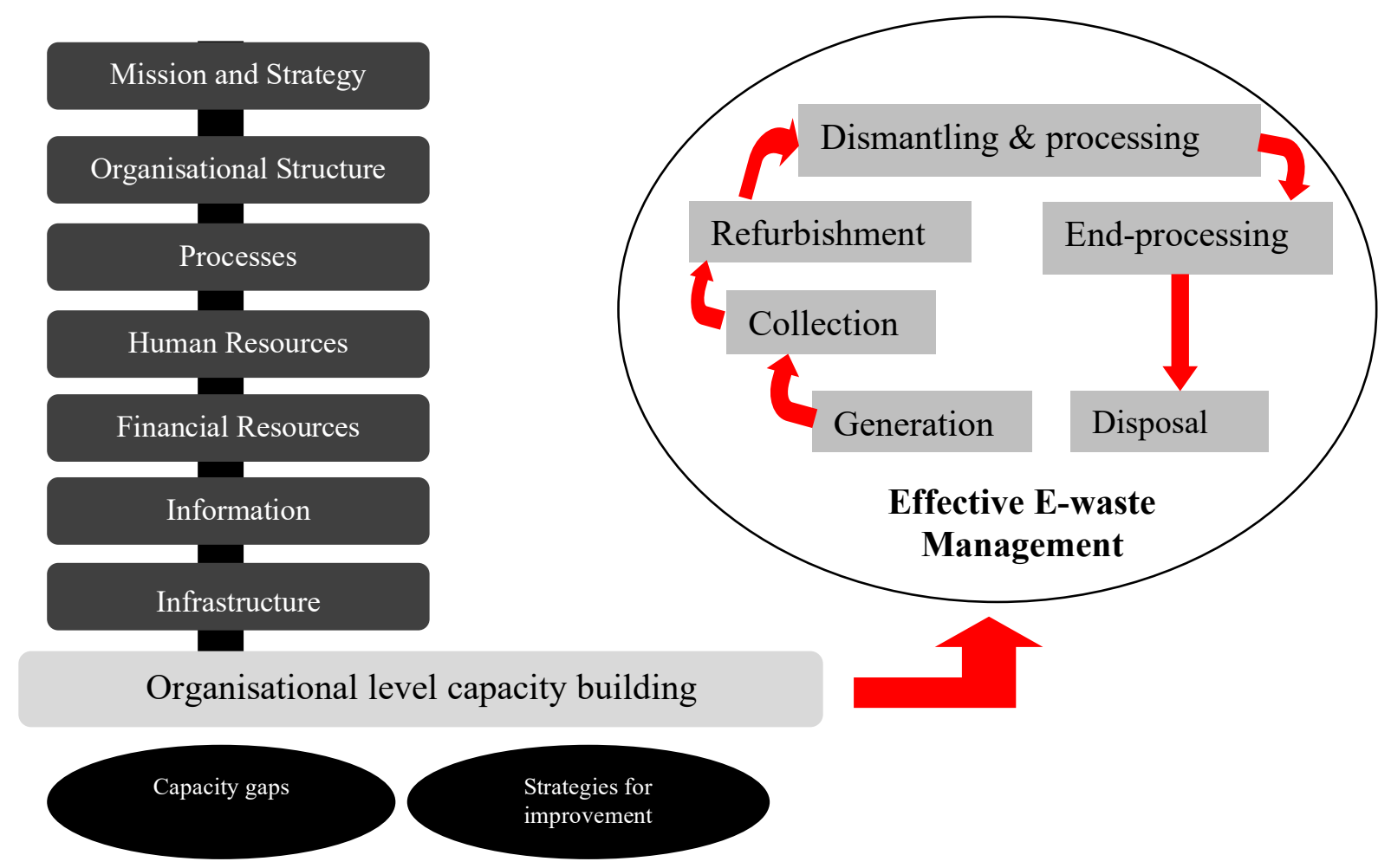

Figure 2: The conceptual framework for effective e-waste management

\section{CONCLUSIONS}

A result of the comprehensive review of the literature suggests that ever-increasing e-waste that has challenged its proper management in developed countries has now extended to developing countries like Sri Lanka. However, it is found that these developing countries are far less having the necessary state of the art of facilities, infrastructure, poor corporate social responsibility of electronic manufacturing industry and relevant legislation which are the basic requirement to manage the e-waste, compared to developed countries. In Sri Lanka, though the government has introduced a national policy on e-waste management together with several other projects collaborated with private sectors, which aim to manage e-waste, still the crisis has not been reduced to the targeted level. These challenges are required to be addressed for the proper management of e-waste. This brought the study to focus on applying the concept of the capacity building into e-waste management which then helps electronic manufacturing organisations to enhance its capacities to break the challenges evolving of ever-increasing e-waste by eliminating the issues which are prevailing as barriers for proper e-waste management. Therefore, this study developed a conceptual framework that applying capacity-building concept for effective e-waste management. The developed framework is a unique one that is the first and foremost, integrate the capacity-building concept to ewaste management, though there are several capacity-building frameworks exist in different disciplines.

However, the scope of the study was limited only to organisation level capacity among the three levels of capacities. Besides, among the different types of solid waste, it only focuses on e-waste and a special emphasis was given on e-waste management practices and involvement of organisational capacities in e-waste management in developing states. 
Consequently, it necessitates that these capacities gaps in an organisation need to be addressed for the effective management of e-waste. Therefore, future research can be taken to enhance the organisational capacities for the proper management of e-waste in Sri Lanka.

\section{REFERENCES}

AFMA. (2015). E-waste management in Sri Lanka. (A. Gunarathne, Ed.) Nugegoda: University of Sri Jayewardenepura.

Adediran, Y. and Abdulkarim, A., 2012. Challenges of electronic waste management in Nigeria. International Journal of Advances in Engineering \& Technology, 4(1), pp.640-648.

Baldé, C.P., Wang, F., Kuehr, R. and Huisman, J., 2015. The global e-waste monitor-2014. Bonn, Germany: United Nations University, IAS-SCYCLE.

Begum, K.J., 2013. Electronic Waste (E-Waste) Management in India: A Review. IOSR Journal of Humanities and Social Science, 10(4), pp.46-57.

Bhutta, M.K., Omar, A. and Yang, X. (2011). Electronic Waste: A Growing Concern in Today's Environment. Economics Research International, pp.1-9.

Blokland, M., Alaerts, G., Kaspersma, J. and Hare, M., 2010. Capacity development for improved water management. CRC Press.

CEA, 2016. Status Report on Electrical and Electronic Waste Management in Sri Lanka. Battaramulla: Ministry of Mahaweli Development and Environment.

Dutta, D. and Goel, S., 2017. Electronic Waste (E-Waste) Generation and Management. In Advances in Solid and Hazardous Waste Management, pp.249-266. Springer, Cham.

Ejiogu, A.R. (2013). E-waste economics: a Nigerian perspective. Management of Environmental Quality: An International Journal, 24(2), pp.199-213.

Enemark, S. and Williamson, I. 2004. Capacity building in land administration - a conceptual approach. Survey Review, 37(294), pp.639-650.

Garlapati, V.K. (2016). E-waste in India and developed countries: Management, recycling, business and biotechnological initiatives. Renewable and Sustainable Energy Reviews, 54, 874-881.

Heeks, R., Subramanian, L. and Jones, C., 2015. Understanding e-Waste Management in Developing Countries: Strategies, Determinants, and Policy Implications in the Indian ICT Sector. Information Technology for Development, 21(4), pp.653-667.

ICTA, 2017. Information and Communication Technology Agency of Sri Lanka. Available from: https://www.icta.lk/projects/nenasala-project-national-telecenter-project/\# [Accessed 22 July 2017].

Imbaruddin, A., 2005. Institutional capacity: an analytical framework. Journal Administration Public, 1(1), pp.1-18.

Jadhav, M.S., 2013. Electronic waste: a growing concern in today's environmental sustainability. International Journal of Social Science \& Interdisciplinary Research, 2(2), pp.139-147.

Jang, Y.C. and Kim, M., 2010. Management of used \& end-of-life mobile phones in Korea: A review. Resources, Conservation and Recycling, 55, pp.11-19.

Kalpana, B. and Prabhavathi, M., 2016. E-waste management. International Journal of Innovative Research in Information Security, 3(9), pp.26-28.

Karunasena, G. and Amaratunga, D., 2015. Capacity gaps in post-disaster construction \& demolition waste management. Engineering, Construction and Architectural Management, 22(4), pp.446-466.

Kibert, N.C., 2004. Extended producer responsibility: a tool for achieving sustainable development. Journal of Land Use \& Environmental Law, 19(2), pp.503-523.

Ladou, J. and Lovegrove, S., 2008. Export of Electronics Equipment Waste. International Journal of Occupational and Environmental Health, 14(1), pp.1-10.

Li, J., Zeng, X. and Stevels, A., 2015. Eco-design in Consumer Electronics: Past, Present, and Future. Critical Reviews in Environmental Science and Technology, 45(8), pp.840-860. 
Lusthaus, C., Anderson, G. and Murphy, E., 1995. Institutional assessment: A Framework for Strengthening Organisational Capacity for IDRC'S Research Partners. Ottawa, ON, Canada: International Development Research Centre.

Mallawarachchi, H. and Karunasena, G., 2012. Electronic and electrical waste management in Sri Lanka: Suggestions for national policy enhancements. Resources, Conservation and Recycling, 68, pp.44-53.

MENR, 2008. The report of the outcome of the study on "Development of a National Implementation Plan for Electrical and Electronic Waste Management in Sri Lanka". Ministry of Environment and Natural Resources.

Nnorom, I. and Osibanjo, O., 2008. Overview of electronic waste (e-waste) management practices and legislations, and their poor application in the developing countries. Resources, Conservation and Recycling, 52, pp.843-858.

OECD, 2006. The Challenge of capacity development: working towards good practice. Paris: Organisation for economic co-operation and development.

Ratnayake, D., Kannangara, S., Marasinghe, M., Rajamanthre, K., Abeywardhene, D., Peiris, N. and Miguntanna, N., 2016. Investigation of public attentiveness, attitude and practice on e-waste management in urban and rural communities in Sri Lanka. In $6^{\text {th }}$ International Research Symposium on Engineering Advancements. Malabe, pp.69-74.

Rodrigo, C., 2013. Utility Vs. Environment: Sri Lanka’s Policy Outlook on Managing “E-Waste. Available from: http:/www.ips.lk/talkingeconomics/2013/06/05/utility-vs-environment-sri-lankas-policyoutlook-on-managing-waste-electrical-and-electronic-equipment/ [Accessed 15 May 2018].

Siano, A., Kitchen, P.J. and Confetto, M.G., 2010. Financial resources and corporate reputation: Toward common management principles for managing corporate reputation. Corporate Communications: An International Journal, 15(1), pp.62-82.

Sivathanu, B., 2016. User's perspective: knowledge and attitude towards e-waste. International Journal of Applied Environmental Sciences, 11(2), pp.413-423.

Sthiannopkao, S. and Wong, M.H., 2013. Handling e-waste in developed and developing countries: Initiatives, practices, and consequences. Science of the Total Environment, 463, pp.1147-1153.

Suraweera, I., 2016. E-waste issues in Sri Lanka and the Basel Convention. Reviews on Environmental Health, 31(1), pp.141-144.

Thavalingam, V. and Karunasena, G., 2016. Mobile phone waste management in developing countries: A case of Sri Lanka. Resources, Conservation and Recycling, 109, pp.34-43.

Tran, C.D. and Salhofer, S.P., 2016. Analysis of recycling structures for e-waste in Vietnam. Journal of Material Cycles and Waste Management, 20(1), pp.110-126.

UNDP, 1998. Capacity assessment and development In a Systems and Strategic Management Context. Technical Advisory Paper No. 3, Management Development and Governance Division, Bureau for Development $\quad$ Policy. Available from: https://www.cbd.int/doc/pa/tools/Capacity\%20assessment\%20and\%20development.pdf [Accessed 21 February 2018].

UNEP, 2010. A Report - Recycling - from E-Waste to Resources. United Nations Environment Programme. Available from: https://wedocs.unep.org/bitstream/handle/20.500.11822/21767/UNEP\%20GPA\%20IGR4-2\%20$\% 20$ Progress $\% 20$ report $\% 2014 \% 20$ September.4.2.pdf?sequence=1\&isAllowed=y [Accessed 16 March 2018]

USAID, 2011. Organisational Capacity Building Framework: A Foundation for Stronger, More Sustainable HIV/AIDS Programs, Organisations \& Networks. Washington, DC.: AIDSTAR-Two Project. Available from: https://www.msh.org/sites/msh.org/files/as2_technical_brief_2 final.pdf [Accessed 25 February 2018].

Wath, S.B., Vaidya, A.N., Dutt, P.S. and Chakrabarti, T, 2010. A roadmap for development of sustainable E-waste management system in India. The Science of The Total Environment, 409(1), pp.19-32.

World Bank, 2017. World Development Indicators 2017. Washington, DC: World Bank. Available from: https://openknowledge.worldbank.org/handle/10986/26447 [Accessed 28 November 2017]. 